\title{
Preparing EFL Learners for Native English-Speaking Context Through Vocabulary Learning: Two Chinese Cases in New Zealand
}

\author{
BAO Chun-rong \\ The University of Auckland, New Zealand
}

\begin{abstract}
While numerous studies in English as a second/foreign language (EFL) have examined vocabulary learning and teaching in the perspective of theories and practical tips, there is a paucity of research on the impact of high-frequency words learning on preparing new EFL residents for the life in English-speaking countries. In order to fill this gap, this study draws on the experience of two EFL learners in New Zealand (NZ), so as to explore the effectiveness of a 16-week daily-English-focused vocabulary learning program, which might generate useful implications about the effective adaption of new EFL residents to their target countries.
\end{abstract}

Keywords: EFL, vocabulary learning, vocabulary teaching, daily English, case study, New Zealand

\section{Introduction}

Numerous studies in English as a second/foreign language (EFL) have examined vocabulary learning and teaching, including theories and practical tips (Nation, 2001). Some researchers defined vocabulary as the words taught in the foreign language (Nation, 2001), whereas some others stressed that vocabulary can be presented, explained, and included in all kinds of activities, but it must be learned by the individual rather than be taught (Banerjee, 2006). While vocabulary learning strategies have been a focus of researchers for a long time ( $\mathrm{Gu} \&$ Johnson, 1996), there is a paucity of research on the impact of daily-English words learning (Nation, 2001) on preparing new EFL residents for the life in English-speaking countries. In order to fill this gap, this study draws on the experience of two EFL learners in New Zealand (NZ), so as to explore the effectiveness of a 16-week vocabulary learning program, which might generate useful implications about the effective adaption of new EFL residents to their target countries. One key research question guides this study: How did the participants become prepared for the new life through vocabulary learning?

\section{This Study}

The vocabulary learning program reported in this case study was embedded in an English course in NZ. This course, based on intermediate daily English, aimed to help students to deploy different learning strategies so as to develop their English proficiency. Vocabulary learning program was a section of the course. In this program, nine EFL learners attended over 16 weeks (two hours per class; twice a week). This program focused 
on daily-English words (Nation, 2001), organized communicative activities, and introduced some vocabulary learning strategies (Nation, 2001). Considering the frequency, coverage, range, availability, learnability, opportunism, and centers of interest (Nation, 2001), the textbook-Get Together 4, published by Oxford University Press, was selected as a guideline in which 16 topics were covered (see Table 1). In addition, students were assigned to accumulate words in supermarkets or shopping malls after class and then share their word accumulation in the next class. 
Table 1

Vocabulary Learning Plan

\begin{tabular}{|c|c|c|c|c|c|c|}
\hline & \multirow[t]{2}{*}{ Topic } & \multicolumn{2}{|c|}{$\begin{array}{l}\text { Content and sequencing } \\
\text { (Nation 2001) }\end{array}$} & \multirow{2}{*}{$\begin{array}{l}\text { Format and presentation } \\
\text { (Nation 2001) }\end{array}$} & \multirow[t]{2}{*}{ Learning goals } & \multirow{2}{*}{$\begin{array}{l}\text { Monitoring and } \\
\text { assessment } \\
\text { (Nation, 2001) }\end{array}$} \\
\hline & & Vocabulary from the text book & Other resources & & & \\
\hline W1 & Parts of an animal & Tail, back, patch, paw, fur... & $\begin{array}{l}\text { Internet } \\
\text { bilingual dictionary }\end{array}$ & $\begin{array}{l}\text { Mnemonic and rote } \\
\text { vocabulary learning } \\
\text { strategies }\end{array}$ & $\begin{array}{l}\text { Match the words with items and be } \\
\text { able to describe pets or other animals }\end{array}$ & $\begin{array}{l}\text { Short-term } \\
\text { achievement }\end{array}$ \\
\hline W2 & Feelings & $\begin{array}{l}\text { Embarrassed, thrilled, worried, } \\
\text { disappointed, relieved... }\end{array}$ & $\begin{array}{l}\text { English movies } \\
\text { Conversation }\end{array}$ & Communicative activities & $\begin{array}{l}\text { Be able to express and understand the } \\
\text { feelings }\end{array}$ & \multirow{3}{*}{$\begin{array}{l}\text { Proficiency } \\
\text { Achievement test } \\
\text { (Read, 2000) }\end{array}$} \\
\hline W3 & $\begin{array}{l}\text { Verbs related to } \\
\text { visiting people }\end{array}$ & Used to do, didn't use to... & Conversation & Communicative activities & Learn how to describe one's past life & \\
\hline W4 & $\begin{array}{l}\text { Vocabulary related } \\
\text { to mailing letters }\end{array}$ & $\begin{array}{l}\text { Mail, receive, deliver, return } \\
\text { address, Envelope, stamp... }\end{array}$ & Post office & $\begin{array}{l}\text { Rote vocabulary learning } \\
\text { strategies }\end{array}$ & Learn to deal with letters & \\
\hline W5 & Outdoor sports & $\begin{array}{l}\text { Climb, hike, fish, ride, camp, } \\
\text { ride, rugby... }\end{array}$ & $\begin{array}{l}\text { Travel agency, "Beautiful } \\
\text { World" (a TV travel } \\
\text { programme introducing } \\
\text { NZ ) }\end{array}$ & $\begin{array}{l}\text { Guessing from context; } \\
\text { Communicative activities }\end{array}$ & Be able to describe leisure activities & \multirow{2}{*}{$\begin{array}{l}\text { Short-term } \\
\text { achievement; } \\
\text { Proficiency }\end{array}$} \\
\hline W6 & School subjects & $\begin{array}{l}\text { Chemistry, Biology, Art, } \\
\text { Geography, P.E.... }\end{array}$ & $\begin{array}{l}\text { Library } \\
\text { Bookshop }\end{array}$ & $\begin{array}{l}\text { Mnemonic and rote } \\
\text { vocabulary learning } \\
\text { strategies }\end{array}$ & $\begin{array}{l}\text { Be able to select lessons } \\
\text { appropriately }\end{array}$ & \\
\hline W7 & Directions words & South, North, East, West... & $\begin{array}{l}\text { Compass; } \\
\text { Map }\end{array}$ & $\begin{array}{l}\text { Mnemonic and rote } \\
\text { vocabulary learning } \\
\text { strategies }\end{array}$ & Learn to read map in the new city & \multirow{3}{*}{$\begin{array}{l}\text { Proficiency } \\
\text { Achievement test } \\
\text { (Read, 2000) }\end{array}$} \\
\hline W8 & Shapes & $\begin{array}{l}\text { Square, rectangle, circle, heart, } \\
\text { diamond, star, triangle... }\end{array}$ & $\begin{array}{l}\text { Geometry book } \\
\text { Conversation }\end{array}$ & $\begin{array}{l}\text { Mnemonic and rote } \\
\text { vocabulary learning } \\
\text { strategies }\end{array}$ & Be able to describe things. & \\
\hline W9 & Sense verbs & $\begin{array}{l}\text { Smell, taste, look, feel, } \\
\text { sound... }\end{array}$ & Conversation & Communicative activities & Be able to describe things & \\
\hline
\end{tabular}


(Table 1 continued)

\begin{tabular}{|c|c|c|c|c|c|c|}
\hline \multirow{2}{*}{\multicolumn{2}{|c|}{ Topic }} & \multicolumn{2}{|c|}{$\begin{array}{l}\text { Content and sequencing } \\
\text { (Nation 2001) }\end{array}$} & \multirow{2}{*}{$\begin{array}{l}\text { Format and presentation } \\
\text { (Nation 2001) }\end{array}$} & \multirow[t]{2}{*}{ Learning goals } & \multirow{2}{*}{$\begin{array}{l}\text { Monitoring and } \\
\text { assessment } \\
\text { (Nation, 2001) }\end{array}$} \\
\hline & & Vocabulary from the text book & Other resources & & & \\
\hline W10 & Places in a town & $\begin{array}{l}\text { Bus stop, department store, } \\
\text { drugstore, gas station, } \\
\text { newsstand... }\end{array}$ & $\begin{array}{l}\text { Road, } \\
\text { Conversation }\end{array}$ & \multirow{6}{*}{$\begin{array}{l}\text { Word cards; } \\
\text { Context; } \\
\text { Mnemonic and rote } \\
\text { vocabulary learning } \\
\text { strategies } \\
\text { Repetition }\end{array}$} & $\begin{array}{l}\text { Know what these places are and where } \\
\text { I should go if I need to }\end{array}$ & \multirow{6}{*}{$\begin{array}{l}\text { Short-term } \\
\text { achievement; } \\
\text { Proficiency } \\
\text { Achievement test } \\
\text { (Read, 2000) }\end{array}$} \\
\hline W11 & $\begin{array}{l}\text { Vegetables } \\
\text { and fruits }\end{array}$ & $\begin{array}{l}\text { Eggplant, onion, mushroom, } \\
\text { broccoli, tempura... }\end{array}$ & $\begin{array}{l}\text { Supermarket } \\
\text { Fruit World } \\
\text { Restaurant... }\end{array}$ & & $\begin{array}{l}\text { Be able to match the words with items, } \\
\text { and then read recipe and order dishes } \\
\text { in restaurants }\end{array}$ & \\
\hline & & $\begin{array}{l}\text { Mustard, pepper, soy sauce, } \\
\text { salt, salad dressing, ketchup... }\end{array}$ & Supermarket & & Be able to understand the recipe & \\
\hline W13 & $\begin{array}{l}\text { Swimming } \\
\text { accessories }\end{array}$ & $\begin{array}{l}\text { Towel, bathing cap, goggles, } \\
\text { bathing suit, bathrobe... }\end{array}$ & $\begin{array}{l}\text { Swimming pool, } \\
\text { Shopping mall }\end{array}$ & & \multirow{3}{*}{ Be able to match the words with items } & \\
\hline W14 & Personal care items & $\begin{array}{l}\text { Soap, shampoo, toothbrush, } \\
\text { toothpaste, Hairbrush, comb... }\end{array}$ & Supermarket & & & \\
\hline W15 & Clothing & $\begin{array}{l}\text { Slipper, jacket, suit, tie, belt, } \\
\text { pant, jeans... }\end{array}$ & Shopping mall & & & \\
\hline W16 & (Phrasal verbs) & $\begin{array}{l}\text { Answer the phone, turn off the } \\
\mathrm{TV} \text {, turn on the coffee } \\
\text { machine, put away the food... }\end{array}$ & $\begin{array}{l}\text { Dictionary } \\
\text { Newspaper } \\
\text { Movies } \\
\text { Conversation... }\end{array}$ & $\begin{array}{l}\text { Communicative activities } \\
\text { context; } \\
\text { Dictionary Use; } \\
\text { Repetition; } \\
\text { Translation } \\
\text { Grammar }\end{array}$ & Master the collocation & Proficiency \\
\hline
\end{tabular}




\section{Participants and Methods}

The participants, Cindy and Sandy (pseudonyms), new residents in NZ less than one month, were invited to participate in this research. Both of them were university graduates from Mainland China (MC), and had no experience of living outside MC. Data were collected through six semi-interviews prior to, during, and at the end of the program. In the interviews, the participants were encouraged to share their motivations for learning English, reflections on learning experience, and expectations for new life in NZ. All the data were transcribed, translated, and analyzed by the researcher. To enhance the validity of the data, member checking was conducted

\section{Findings}

This study demonstrates that both contents and instructional strategies in the program largely contributed to the participants' growth as new residents.

First of all, the contents of this program mapped out a scene for the participants to engage in daily life, such as conversational topics and necessities for life. At the beginning, both of them had capability to perform well in English exams based on grammatical or structural syllabus, but they did not have sufficient control of the essential daily-English words, such as the names of necessities for life (Nation, 2001). As Cindy said, "it was difficult for me to tell the names of commodities in supermarket... One day when I wanted to buy toner, I asked 'where I could find water keeping face wet'... I felt like an idiot then..." despite her 8.0 (of 9.0) grade in Reading Test of IELTS. Sandy also mentioned that he could read academic English, but had little knowledge of local life; he also noted that "I was eager to talk with native people, but did not know what to talk... I even did not know the difference between copy and print..." However, after the program, not only could they recognize these words, but also became confident and fluent in using them. As Cindy said, "I once thought supermarket was like an alien world, because I did not know what was on the shelves... Now I can find out anything I want to buy... I like it..." The same confidence was also evident in Sandy, who realized that "I'm not afraid to communicate with others any more... Everyone was interested in shopping... Nobody would refuse to talk about food..."

Second, the strategies taught in this program created a platform for the EFL learners to share experiences and collaborate incidental learning with intentional learning (Nation, 2001). At the beginning, students preferred to look up dictionaries when they encountered unfamiliar words, when intentional learning was their first or sole option. As Cindy reflected, "if I did not see the meaning in the dictionary, I had no confidence that I did understand it..." So did Sandy, who brought his electronic dictionary wherever he went. Through this program, they started to pay attention to local news and learn new words via collecting and guessing in daily life, such as watching English movies and communicating with local people. As some examples shared by Cindy, "I leant the meanings of 'out of the blue', 'foreign body' in hospital... it's amazing that they could be used in this way... Oh, yes, 'amazing' is also the one I picked up..." Sandy also shared proudly that he had also learnt some slangs with local friends, "I don't know how to say them in Chinese, but I know when to use them..." In addition to learning strategies, these changes have revealed that both Cindy and Sandy, to some extent, started to become the members of the society.

\section{Discussion and Conclusion}

This study reports on a vocabulary learning program whereby two EFL new residents learned to adapt 
themselves to the new life in NZ. Both the participants benefitted from a wide range of resources in terms of learning contents and vocabulary learning strategies. Learning contents not only widened their horizon on local topics, but also increased their accumulation of daily-English words. These learning strategies developed their language skills and proficiency, connected their academic classrooms with real outdoor life (Thomson, 2016), and also fostered their autonomy of language learning (Gao \& Zhang, 2011). These experiences and insights, otherwise, might be accumulated from daily life at a slower pace. It should be emphasized that these changes were accompanied by participants' high expectation for native-like life and strong motivation to transfer their roles from language learners to language users, and then to the local members of the society. It was these changes that indeed cultivated their confidence and optimism in the process of adaption, which might also shed a useful light on their future. In this sense, daily-English-words-focused vocabulary learning program can truly become a pathway towards life in target countries.

This small-scale case study provides a strong impetus for bringing innovation to the design of vocabulary learning and teaching for new EFL residents, as well as some insights into the preparation of the EFL people who aspire to study or live in English-speaking countries. Provided the limited scope of the study, further research is suggested. This may include more participants of different target languages or of different levels of language proficiency to broaden the horizon of the effectiveness of taking daily-English words as a breakthrough.

\section{References}

Banerjee, A. K. (2006). Teaching English as a foreign language. India: Pointer Publishers.

Gao, X. S., \& Zhang, L. J. (2011). Joining forces for synergy: Agency and metacognition as interrelated theoretical perspectives on learner autonomy. In G. Murray, X. S. Gao, \& T. Lamb (Eds.), Identity, motivation and autonomy in language learning (pp. 25-41). Bristol, UK: Multilingual Matters.

Gu, Y., \& Johnson, R. K. (1996). Vocabulary learning strategies and language learning outcomes. Language Learning, 46(4), 643-679.

Nation, I. S. P. (2001). Learning vocabulary in another language. Cambridge, UK: Cambridge University Press.

Thomson, C. (2016). Understanding life in school: From academic classrooms to outdoor education. Journal of Education for Teaching, 42(3), 369-370. 